\title{
Skills Required by Teachers to Carry out their Activities in Wood Workshops in Tertiary Institutions in North Western Nigeria
}

\author{
Umar, Lawal \\ Federal College of Education (Technical) Bichi, Kano State
}

Doi:10.5901/jesr.2014.v4n7p108

\begin{abstract}
The concerned of this study emanated from poor performance in woodwork and low declining skills in performance among tertiary institutions graduates in the North Western Nigeria. The study therefore, focused on the Skills Required by Teachers to carry out their Activities in Wood workshops in Tertiary Institutions in North Western Nigeria. Two research questions were asked and two hypotheses formulated and were tested at 0.05 level of significant. A questionnaire titled 'Skills Required by Tertiary level Woodwork Teachers (QSRTWT), consisting of 37 items was structured based on the two research questions: Cutting, Planing, Joint making and Assembling were administered to forty woodwork teachers in seven tertiary institutions in North Western Nigeria (Kano, Kaduna, Katsina, Kebbi, Sokoto and Zamfara states). Data collected were analyzed using the Mean and answered the research questions and t-test statistic was used and tested the hypotheses at 0.05 level of significant. The result of the research questions showed that all the 37 woodwork skills were required by the tertiary institutions teachers. The hypotheses tested revealed that there is no significant difference in the mean responses of the Experienced and Less experienced teachers. Therefore, the result of the study showed that there is the need for re-training of teachers in woodwork skills for effective transfer of same to the learners. The study recommended that continuous training and re-training of woodwork teachers in woodwork skills through in service training, workshop and seminars to update their skills is necessary.
\end{abstract}

Keywords: skills, woodwork, teachers, tertiary institutions.

\section{Introduction}

Woodwork is a course of study which enabled an individual to acquire skills in theory as well as practical aspect of the subject (woodwork). But the emphasis is more on the skill acquisition in order to provide students with skill for self reliance. According to Agbo (2000), woodwork technology is that type of training intended to prepare the students to earn a living in an occupation in which success is dependant largely on understanding of technology as applied to modern technology and design. This type of education provides skills, knowledge and attitudes for effective occupation (Okoro, 2000).

The success of woodwork programme depends largely on the effectiveness of woodwork teachers to operate, use and maintain the basic woodwork tools and equipment provided in the workshops. Where woodwork teachers could not operate, use and maintain woodwork equipment for continues use in training woodwork students, technical training programmes will suffer, this will lead to the production of highly unskilled personnel who are unemployable and unproductive. According to Sara (2000), more than $60 \%$ of the staff teaching woodwork in tertiary institutions could not perform the skills or provide technical services they were expected to teach others despite their high level paper qualification. This is of course due to non-skill acquisition from their respective institutions of higher learning.

Tertiary institutions are institutions that provide an advance education after secondary education in universities, colleges of education, polytechnics, monotechnics, including those institutions offering correspondence courses (FGN, 2004).

Woodwork programme in tertiary institutions is design to provide theoretical and practical skills by exposing students to drill practices for mastery in the use of tools and equipment for Cutting, planing, construction of joints, assembling of woodwork articles, applying different types of finishes on furniture article as well as maintenance of tools and equipment in the workshop. Woodwork is one of the courses offered in technical education.

Technical Education is a course of study that enables an individual to address the complex demands of the environment, through the production of tangible goods and services for the benefit of the society. The goal of Technical Education according to Onwuegbuna (2003) is the transmission of ideas, skills, knowledge and values of work and what an individual can do with his or her life. Therefore, Technical Education enables an individual to acquire ideas and skills 
for self-reliance.

The term skill could be defined as the level of efficiency achieved or attained through repetitive performance of an operation. Ezeji (2003) referred to skill as a well established habit of doing something in the most economical way involving the acquisition of performance capabilities. According to Abdullahi (2010), skill is the capability of accomplishing a job with precision, cleverness and expertise. It is therefore, necessary for a woodwork teacher to acquire some skills that would enable the woodwork teacher to impart same to the learners. Okorie and Ezeji (1988) remarked that to possess a skill is to demonstrate the habit of acting, thinking or behaving in a specific activity which has become so natural to the individual through repetition or practice that may become automatic. Ogwo and Oranu (2006) stated that, skill requires actual muscular movement of the fingers, hands, arms and other parts of the body, coordinated with the eye and sometimes the ear. Such movements according to Ogwo and Oranu, involve the use of hand tools, instruments and machines. Careful consideration reveals that when such skills are fully learned, they become fixed muscular habits.

Habits according to Ogwo and Oranu, is a way of doing something which when learned does not require active thinking in order to do it subsequently. Many actions that people perform frequently become habit that is they become automatic by practice. A carpenter in sawing to a line does not exert conscious mental control over each muscular movement as the sawing proceeds. The correct grasp of the saw, the correct angle of the saw to the work, correct pressure and length of strokes have all become habitual through long practice, by watching an experienced woodwork teacher performs the actions in the workshop.

A teacher is a professional person, a leader, an important personality in the classroom situation who is highly knowledgeable in the subject matter. The teacher is not a material that can be created overnight. It takes a long time to train a teacher. The teacher is important because no matter what material is on the ground, a student cannot teach himself/herself effectively without the guidance of a teacher (Adewumi, 2009). The teacher in relation to this study is a wood worker who has acquired professional training in teaching with relevant skills in the use of hand tools and machines. In tertiary institutions, wood workers are generally professional teachers or instructors who have served for many years and are regarded as experienced teachers.

Experience teachers are those teachers who possessed knowledge and skills through involvement in or exposure to something over a period of time. A person with considerable experience can gain a reputation as an expert. Therefore woodwork teachers that served from six years and above with regard to this study are regarded as experienced teachers. Among these teachers there are some that have served for less than six years these are regarded as less-experienced teachers. These groups make use of wood workshops where some important improvement in skills required becomes necessary. The skills expected of a woodwork teacher to possess and pass to the students include: cutting, planing, joint making skills. Others are wood project assembling skills, wood finishing and finishes application and maintenance of woodwork tools and equipment skills.

This study is carried out on two areas of woodwork skills that is, cutting, planing, joint making and assembling of wood article. Cutting is the separation of a physical object into two or more portions, through the application of an acutely directed force (Bureau, 2012). According to the Bureau, cutting is a compressive and shearing phenomenon and occurs only when the total stress generated by a cutting implement exceeds the ultimate strength of the material of the object being cut. Cutting also describes the action of a saw which removes material in the process of cutting wood John (1994). Beside cutting, planing is the next skill a teacher should acquire for effective workshop operation. Planing is the smoothing of surfaces and edges of sawn timber by taking off shavings by planes (Walton 1976). Planing is removing of imperfections of the piece of wood to make it smooth and attractive. Planing is a vital skill which enable a woodworker to construct a perfect joint for furniture making . Joint is a connection used to put two or more parts together.

Joints in woodwork are devices for holding parts of wooden artifacts or structures together (Sackey, 1999). According to the Sackey, there are varieties of joints and those used for cabinet construction may be categorized into three: widening joints, angle joints, and framing joints. When joints are constructed for the purpose of making an article, they are assembled with either adhesives or mechanical fasteners (nails and screws). Assembling means to collect together or fit different parts together. Assembling in woodwork is the collection of different part of furniture or wooden article together to form a whole using adhesives or mechanical fasteners (screws, butts and nails).

For woodwork teachers to effectively teach sawing planing, joint making and assembling skills in the wood workshop, the teachers need to possess the required skills for effective transfer to their students.

However, these skills are lacking on the part of woodwork technology teachers in tertiary institutions as stated by Oranu(2001) that technical college products are weak in the practice of their trades. In addition, the standard of performance of Nigerian technical graduates in general is at the moment very low thereby retarding the overall 
productivity of Nigerian economy (Okorie, 2001). , Ogundeji (2012), rightly observed that the problem facing technical institution in Nigeria is that of production of un skilled technical personnel who cannot function effectively in the society. According to Ogundeji, the above situation is attributed to lack of skills on the part of tertiary institution teachers or they are weak in teaching practical skills to the student in their school wood workshops

Students graduating from tertiary institutions with low level skills find it very difficult to adjust to changing technology in their field. Retraining of these graduates may be very expensive on the part of individuals and government. In order to train students properly in woodwork skills for effective participation in the world of work, the skills of teachers need to be improved to enable woodwork teachers use the wood workshop for effective teaching and learning. It is against this backdrop therefore that the study is undertaken to find out the skills required by teachers to carry out their activities in wood workshops in tertiary institutions in North Western Nigeria.

\subsection{Research Questions}

The following research questions are formulated to guide the study:

1. What are the skills required by woodwork teachers in cutting, planing and joint making in wood workshops in tertiary institutions in North Western Nigeria?

2. What are the skills required by woodwork teachers in the assembling of woodwork projects in wood workshops in tertiary institutions in North Western Nigeria?

\subsection{Hypotheses}

The following hypotheses will be tested at 0.05 level of significance:

$\mathrm{H}_{1}$ :There is no significant difference in the mean responses of experienced and Less-experienced teachers on the skills they require for wood cutting, planing and Joint making in the workshop.

$\mathrm{Ho}_{2}$ :There is no significant difference in the mean responses of experienced and Less-experienced teachers on the skills they require in assembling woodwork projects.

\subsection{Methodology}

Descriptive survey research design was adopted for the study. The use of this design for this study is appropriate because it allow the researcher to elicit information from the respondents. The population for this study consists of 46 woodwork teachers from the eight selected tertiary institutions in North Western Nigeria. The population is made up of 24 teachers from four Colleges of Education and 22 teachers from four Polytechnics in the zone. Since the population of the woodwork teachers in the zone is small the entire population was used for the study.

\subsection{Instrument for Data Collection}

The instrument for data collection was a structured questionnaire titled Questionnaire of Skills Required by Tertiary level Woodwork Teachers (QSRTLWT), which consisted of 37 items. A five point Likert scale was used the response options are as follows:Very highly required (VHR), Highly required (HR), Moderately required (MR), Slightly required (SR) and Not Required (NR). Three lecturers validated the instrument; reliability of the instrument was established using test- retest technique. Pearsons product Moment Correlation Coefficient was used to correlate the result. The result obtained revealed a positive correlation of ' $r=0.97$.

Data collected was analyzed using mean, two hypotheses stated, were tested using t-test at 0.05 level of significance. For decision making, the real limit of numbers for the likert scale was used for interpretation as follows: 4.50 - $5.00=$ Very highly required (VHR), $3.50-4.49=$ Highly required (HR), 2.50 - $3.49=$ Moderately required (MR), 1.50 $2.49=$ Slightly Required (SR)

$0.50-1.49=$ Not Required (NR). Any Mean value between 3.50 to 5.00 means required while any value from 3.49 and below implied not required.

\section{Result}

The result of the analysis of the study are presented in tables 1 to 4 below 
Research Question 1: What are the skills required by woodwork teachers in cutting, planing and joint making in wood workshops in tertiary institutions in the North Western Nigeria?

Answer to this research question is presented in Table 1.

Table 1: Mean Rating of the Responses of Experienced and Less Experienced Woodwork Teachers on the Skills Required in Cutting, Planing and Joint making in Wood Workshops in Tertiary Institutions in North Western Nigeria

\begin{tabular}{clcc}
\hline S/NO & Item Statement & Mean & REMARK \\
\hline 1 & correct grasp of the saw handle while cutting & 4.45 & $\mathrm{HR}$ \\
2 & Rip along the grain & 4.13 & $\mathrm{HR}$ \\
3 & Cut across the grain & 4.05 & $\mathrm{HR}$ \\
4 & cut small tenons & 3.98 & $\mathrm{HR}$ \\
5 & Cut concave and convex curves & 3.92 & $\mathrm{HR}$ \\
6 & Set of gauge on a circular sawing machine & 4.58 & $\mathrm{HR}$ \\
7 & Cut mitre on a circular saw machine & 3.95 & $\mathrm{HR}$ \\
8 & Handle stock while cutting on circular saw & 4.10 & $\mathrm{HR}$ \\
9 & Cut and trenches using circular saw & 3.78 & $\mathrm{HR}$ \\
10 & The use of push stick & 3.70 & $\mathrm{HR}$ \\
11 & Handle plane correctly & 4.45 & $\mathrm{HR}$ \\
12 & Set correct level of cutting iron & 4.15 & $\mathrm{HR}$ \\
13 & Correct grasp of the handle and the toe & 3.83 & $\mathrm{HR}$ \\
14 & Plane the face side & 4.15 & $\mathrm{HR}$ \\
15 & Plane the face edge & 4.13 & $\mathrm{HR}$ \\
16 & Test flatness using Try -square and winding stick & 4.45 & $\mathrm{HR}$ \\
17 & Correct use of marking gauge & 4.03 & $\mathrm{HR}$ \\
18 & Plane end grains & 4.35 & $\mathrm{HR}$ \\
19 & Set depth of cut of a jointer machine & 3.85 & $\mathrm{HR}$ \\
20 & Feed stock on the planer & 4.00 & $\mathrm{HR}$ \\
21 & Sett of the front table of a planer & 4.10 & $\mathrm{HR}$ \\
22 & Correct use of a push block & 4.08 & $\mathrm{HR}$ \\
23 & Correct use of try square in marking out joints & 4.30 & $\mathrm{HR}$ \\
24 & Correct application of marking gauge in gauging lines & 4.60 & $\mathrm{HR}$ \\
25 & Set sliding bevel when marking out dovetail joint & 4.25 & $\mathrm{HR}$ \\
26 & Using backsaws in cutting out waste & 3.65 & $\mathrm{HR}$ \\
27 & Correct use of chisels and mallet to remove wastes. & 4.35 & $\mathrm{HR}$ \\
\hline
\end{tabular}

Data in Table 1 on skills required by teachers in cutting, planing and joint making indicates that all 27 skills are highly required. All the items have a Mean score between 3.70 and 4.60 .

Research Question 2: What are the skills required by woodwork teachers in assembling of woodwork projects in wood workshops in tertiary institutions in North Western Nigeria?

Answer to this research question is presented in Table 2.

Table 2: Mean Rating of the Responses of Experienced and Less Experienced Woodwork Teachers on the Skills Required in Assembling Wood Project in Wood Workshops in Tertiary Institutions in North Western Nigeria

\begin{tabular}{llll}
\hline S/NO & Item Statement & Mean & Remark \\
\hline 28 & Interpret working drawing & 4.48 & $\mathrm{HR}$ \\
29 & Correct use of cramps and clamps & 4.45 & $\mathrm{HR}$ \\
30 & Correct use of scrap blocks when assembling projects & 4.00 & $\mathrm{HR}$ \\
31 & Trail assembling of the project & 4.10 & $\mathrm{HR}$ \\
32 & Sub - assembling of large projects & 4.10 & $\mathrm{HR}$ \\
33 & Apply Glue & 3.98 & $\mathrm{HR}$ \\
34 & Removal of surplus glue & 3.70 & $\mathrm{HR}$ \\
35 & Test squareness of the work before final clamping & 4.30 & $\mathrm{HR}$ \\
36 & Knock down fitting assembly & 3.75 & $\mathrm{HR}$ \\
37 & Assemble using screw and nails & 3.95 & $\mathrm{HR}$ \\
\hline
\end{tabular}


Data in Table 2 on skills required by teachers in assembling wood projects indicated that all the 10 assembling skills are highly required by woodwork teachers. All the items have Mean scores between 3.70 and 4.48 .

\section{Test of Hypotheses}

The four hypotheses were formulated for this study. Data for testing them and the findings are presented below in Table 5 to 8.

\section{Hypothesis One}

There is no significant difference in the mean responses of experienced and less experienced teachers on the skills they require for wood cutting, planing and joint making in the wood workshop.

The data for testing hypothesis one are presented in Table 5.

Table 2: The t-test Analysis of Mean Ratings of the Responses of Experienced and Less Experienced Woodwork Teachers on the Skills they Required for Wood Cutting, Planing and Joint making in Wood Workshops in Tertiary Institutions in North Western Nigeria

\begin{tabular}{|c|c|c|c|c|c|}
\hline \multirow{2}{*}{$\mathrm{S} / \mathrm{NO}$} & \multirow{2}{*}{ Item Statement } & Experienced & Non-Experienced & \multirow{2}{*}{ t-cal } & \multirow{2}{*}{ Remarks } \\
\hline & & Teacher $\quad \bar{X}_{1}$ & Teacher $\quad \bar{X}_{2}$ & & \\
\hline 1 & correct grasp of the saw handle while cutting & 4.62 & 4.14 & 1.799 & NS \\
\hline 2 & Rip along the grain & 4.00 & 4.36 & -1.189 & NS \\
\hline 3 & Cut across the grain & 4.12 & 3.93 & .943 & NS \\
\hline 4 & cut small tenons & 4.15 & 3.64 & 2.203 & $\mathrm{~S}$ \\
\hline 5 & Cut concave and convex curves & 4.00 & 3.75 & .714 & NS \\
\hline 6 & Set of gauge on a circular sawing machine & 4.42 & 4.86 & -2.324 & NS \\
\hline 7 & Cut mitre on a circular saw machine & 4.08 & 3.71 & 1.482 & NS \\
\hline 8 & Handle stock while cutting on circular saw & 4.31 & 3.71 & 3.134 & S \\
\hline 9 & Cut and trenches using circular saw & 3.69 & 3.93 & -.854 & NS \\
\hline 10 & The use of push stick & 3.85 & 3.43 & 1.089 & NS \\
\hline 11 & Handle plane correctly & 4.38 & 4.57 & -.639 & NS \\
\hline 12 & Set correct level of cutting iron & 4.23 & 4.00 & .902 & NS \\
\hline 13 & Correct grasp of the handle and the toe & 3.58 & 4.29 & -2.527 & NS \\
\hline 14 & Plane the face side & 4.27 & 3.93 & 1.156 & NS \\
\hline 15 & Plane the face edge & 4.12 & 4.14 & -.096 & NS \\
\hline 16 & Test flatness using Try -square and windingstick & 4.46 & 4.43 & .120 & NS \\
\hline 17 & Correct use of marking gauge & 3.96 & 4.14 & -.483 & NS \\
\hline 18 & Plane end grains & 4.31 & 4.43 & -.491 & NS \\
\hline 19 & Set depth of cut of a jointer machine & 3.85 & 3.86 & -.044 & NS \\
\hline 20 & Feed stock on the planer & 4.00 & 4.00 & 0.000 & NS \\
\hline 21 & Sett of the front table of a planer & 4.15 & 4.00 & .650 & NS \\
\hline 22 & Correct use of a push block & 4.04 & 4.14 & -.340 & NS \\
\hline 23 & Correct use of try square in marking out joints & 4.46 & 4.00 & 1.811 & NS \\
\hline 24 & Correct application of marking gauge in gauging lines & 4.62 & 4.57 & .222 & NS \\
\hline 25 & Set sliding bevel when marking out dovetail joint & 4.38 & 4.00 & 1.102 & NS \\
\hline 26 & Using backsaws in cutting out waste & 3.69 & 3.57 & .351 & NS \\
\hline 27 & Correct use of chisels and mallet to remove wastes. & 4.31 & 4.43 & -.491 & NS \\
\hline
\end{tabular}

Data in Table 5 indicates that the $t$ - test analysis of the Mean responses of experienced and less experienced teachers on skills they required in wood cutting, planing and joint making in wood workshops in tertiary institutions in North Western Nigeria. The analysis shows that two items (4 and 8) have calculated $t$ - values more than the table $t-$ value of 1.96 at 38 degrees of freedom at 0.05 level of significance. The null hypothesis of no significant difference in the Mean rating of experienced and less experienced woodwork teachers was, therefore, accepted from the analysis. It can be inferred that experienced and less experienced woodwork teachers shared common opinions on these items.

Hypothesis Two: There is no significant difference in the Mean responses of experienced and less experienced teachers on the skills they require in assembling woodwork project in wood workshops in tertiary institutions in North 
Western Nigeria .

The data for testing hypothesis two are presented in Table 6.

Table 4: The t-test Analysis of Mean Ratings of the Responses of Experienced and Less Experienced Teachers on the Skills they Required on Assembling Woodwork Projects in Wood Workshops in Tertiary Institutions North Western Nigeria

\begin{tabular}{|c|c|c|c|c|c|}
\hline \multirow{2}{*}{ S/NO } & \multirow{2}{*}{ Item Statement } & Experienced & Non-Experienced & \multirow[b]{2}{*}{$\mathrm{t}$} & \multirow{2}{*}{ Remarks } \\
\hline & & Teacher $\quad \bar{X}_{1}$ & Teacher $\quad \bar{X}_{2}$ & & \\
\hline 28 & Interpret working drawing & 4.65 & 4.14 & 1.956 & NS \\
\hline 29 & Correct use of cramps and clamps & 4.38 & 4.57 & -.687 & NS \\
\hline 30 & Correct use of scrap blocks when assembling projects & 3.85 & 4.29 & -1.397 & NS \\
\hline 31 & Trail assembling of the project & 3.96 & 4.36 & -1.726 & NS \\
\hline 32 & Sub - assembling of large projects & 4.00 & 4.29 & -1.224 & NS \\
\hline 33 & Apply Glue & 4.00 & 3.93 & .239 & NS \\
\hline 34 & Removal of surplus glue & 3.92 & 3.29 & 1.814 & NS \\
\hline 35 & Test squareness of the work before final clamping & 4.46 & 4.00 & 1.897 & NS \\
\hline 36 & Knock down fitting assembly & 3.85 & 3.57 & 1.070 & NS \\
\hline 37 & Assemble using screw and nails & 3.96 & 3.93 & .120 & NS \\
\hline
\end{tabular}

Data in Table 6 indicates that the t-test analysis of experienced and less experienced teachers on skills they require in assembling woodwork project. The analysis shows that all items have calculated t-values less than the table t-value of 1.96 at 38 degrees of freedom at 0.05 levels of significance. The null hypothesis of no significant difference in the Mean rating of experienced and less experienced woodwork teachers was therefore accepted based on the analysis, it can be inferred that experienced and less experienced teachers shared identical opinions on these items.

\section{Discussions of the Findings}

The skills required by woodwork teachers in cutting,planning and joint making in wood workshops in tertiary institutions were analyzed and established as being required by woodwork teachers. This finding is in line with Sara (2000) that more than 60 per cent of the staff teaching woodwork in tertiary institutions could not perform the skills or provide technical services they were expected to teach others despite their high level paper qualification. Therefore, there is need for retraining of teachers to update their knowledge and skills in woodwork.

The analysis of research question two presented in table 2 provided such findings as indicated by the Mean ratings of woodwork teachers, the skills required by woodwork teachers in assembling of wood articles in wood workshops were all agreed as being required. This indicates that teachers are deficient in skills in planing woodwork projects. This called for retraining of woodwork teachers to keep them abreast with the trend of events. This finding is in line with Hackett (1979) who pointed out that the purpose of retraining is a means of improving the present job performance. There should be constant retraining of woodwork teachers to make them up-to-date for effective discharge of their duties in the wood workshop.

\subsection{Null Hypotheses}

The result of the null hypothesis shows that there is no significant difference in the skills required by experienced and less experienced woodwork teachers on wood cutting, planing, joint making and assembling of woodwork article. This means that the skill required by experienced and less experienced teachers are the same.

\subsection{Summary of Findings}

From the analysis of data, the following findings were made from the study:

1. The woodwork teachers in tertiary institution in North Western Nigeria did not have the required skills in wood cutting, planing, joint making and assembling of wood project during their pre-service training.

2. It was found out that the in ability of the tertiary institutions graduates to function effectively after graduations in the North Western Nigeria, is attributed to lack of the required woodwork skills of their teachers. 
3. It was found that woodwork teachers in tertiary institutions in North Western Nigeria required skills training in wood cutting, planning,joint making and assemblingof articles.

\section{Conclusion}

Based on the findings of this study, it can be concluded that woodwork teachers in tertiary institutions in North Western Nigeria required improvement on the following woodwork skills: wood cutting, planing, joint making and assembling of wood project for effective teaching and learning of woodwork skills.

\section{Recommendations}

The following recommendations are made from this study:-

1. The identified skills required by teachers of woodwork should form the basis for the workshop training to be organized by the training institution as an in-house training.

2. Emphasis should be attached to practical examination after each semester, in order to instill in the learners the importance of practical exercise for skill acquisition. This will also make the tertiary institution teachers to strive hard to update their skills for imparting same to the learners.

The above recommendations if implemented will no doubt improve the skills of woodwork teachers for carrying out their activities in wood workshops in tertiary institutions in North Western Nigeria.

\section{References}

Abdullahi, S. (2010). Electrical installation competencies required by electrical/electronic teachers in Bauchi and Gombe states technical colleges. Unpublished M.Ed Thesis, University of Nigeria, Nsukka.

Ademumi, H.T. (2009). Effective utilization of information and communication technology (ICT) in the teaching of Science Education. Bichi Journal of Technology Education, 1(1), 66 - 67.

Agbo, B.C. (2000), Functional vocational education in Nigeria public schools. A Journal of Nigeria Vocational Association (NVA), 11, 4548.

Bureau, of labour statistics (2012).U.S. Department of labour occupational outlook Handbook, (12 Edition). Wood workers on the internet at $h$ ttp://www.b/s.gov/ productionwoodworkershtm.Retrieved on 21st May, 2012).

Ezeji, S.C.O.A. (2003). Guidance and counselling in education.Enugu: Chuldson International

Federal Government of Nigeria (2004), National Policy of Education. Lagos: National Education Research and Development Council Press.

John, L. (1994). Wood technology and processes fourth edition. New York, USA:Harper Collins Publishers Ltd.

Ogundeji, A.O. (2002), Issues in and challenges facing technical education graduates in

Nigeria. Bichi journal of Technology Education (1), 99.

Ogwo, B.A. \& Oranu R.N. (2006). Methodology in formal and non-formal technical/vocational education.Enugu: ljejas Printers and Publishers Company.

Okorie, J.U. (2001). Vocational industrial education. Bauchi: League of Researchers in Nigeria (L.R.N).

Okoro, O.M. (1993), principle and methods in vocational and technical education. Nsukka: University Trust Publishers.

Onwegbuna, R.O. (2003). Assessment of the utilization level of facilities for teaching and learning of Metalwork in Vocational Technical Colleges in Benue State of Nigeria. Unpublished M.Ed. thesis, University of Nigeria, Nsukka

Oranu, R.N(2001). Vocational and technical education in Nigeria, A paper presented at the international bureau of education (IBE). Sub regional Seminar and workshop on strategies for Teachers Coping with new Curriculum on NVA. 11-17-A Scan, Badagry.

Sara, H.A.(2001), the production of technology teachers for development in Nigeria: problems and strategies. Pankshin Journal of Vocational Education,3(1), 12.

Sackey, J.K.N. (1999) The motivate woodwork, Macmillan Education Ltd. London and Basingstoke. 